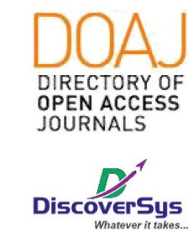

Published by DiscoverSys

\section{Karsinoma sel basal tipe nodular yang diterapi dengan bedah eksisi elips dan anastesi tumesen}

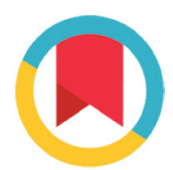

CrossMark

\author{
I Gusti Nyoman Darmaputra ${ }^{1 *}$, Made Wardhana', I Gde Nengah Adhilaksman', \\ I Gusti Ayu Agung Elis Indira ${ }^{1}$, Nyoman Suryawati ${ }^{1}$
}

\title{
ABSTRACT
}

Background: Basal cell carcinoma (BCC) has a very slow-growing and rarely metastatic nature but tends to be locally invasive and relapse after therapy. Elliptical excision is one of the surgical procedures in the field of dermatology which is most often used with the application of tumescent techniques.

Case Description: A woman, 64 years old, no. CM. 18.03.11.71, Balinese tribe, on July 30, 2018, came to the Dermatology and Venerology Polyclinic at Sanglah General Hospital with a frequent symptom of arising from wounds on the forehead. The lession began one year ago. Initially, it was a small reddish lump which was then felt more and more dilated as well as became blackish and accompanied by itching. Dermatology examination revealed hyperpigmentation, solitary, oval, $3 \times 2 \mathrm{~cm}$, multiple erosion, firm boundary, round shape, $0.3-0.4 \mathrm{~cm}$ in diameter, covered in black crusting on top.

Conclusion: The diagnosis of $\mathrm{BCC}$ determined on anamnesis, physical examination, dermoscopy, and histopathology regard with standard ellipse excision surgery.

Keywords: Basal cell carcinoma, elliptical excision, tumescent

Cite This Article: Darmaputra I.G.N., Wardhana, Made., Adhilaksman, I.G.N., Indira, I.G.A.A.E., Suryawati, N. 2019. Karsinoma sel basal tipe nodular yang diterapi dengan bedah eksisi elips dan anastesi tumesen. Intisari Sains Medis 10 (1): 192-196. D0I: 10.1556/ism.v10i1.439

'Departemen Dermatologi dan Venerologi, Fakultas Kedokteran, Universitas Udayana, Rumah Sakit Umum Pusat Sanglah, DenpasarBali

\footnotetext{
* Corresponding: I Gusti Nyoman Darmaputra Departemen Dermatologi dan Venerologi, Fakultas Kedokteran, Universitas Udayana, Rumah Sakit Umum Pusat Sanglah, DenpasarBali

darmaputra@unud.ac.id
}

Diterima : 13-03-2019

Disetujui : 26-03-2019

Diterbitkan : 01-04-2019

\section{ABSTRAK}

Latar Belakang: Karsinoma sel basal (KSB) memiliki sifat tumbuh dan berkembang sangat lambat dan jarang metastasis, namun memiliki kecenderungan invasif lokal dan kambuh setelah dilakukan terapi. Eksisi elips merupakan salah satu prosedur bedah dalam bidang dermatologi yang paling sering digunakan dengan aplikasi teknik tumesen.

Deskripsi Kasus: Seorang perempuan, 64 tahun, no. CM. 18.03.11.71, suku Bali, pada tanggal 30 Juli 2018 datang ke Poliklinik Kulit dan Kelamin Rumah Sakit Sanglah dengan keluhan utama timbul luka pada dahi. Luka tersebut mulai timbul sejak
1 tahun yang lalu. Awalnya lesi berupa benjolan kecil berwarna kemerahan yang kemudian makin lama dirasakan makin melebar dan menjadi berwarna kehitaman serta disertai rasa gatal. Pemeriksaan dermatologi pada lokasi dahi (frontalis) tampak plak hiperpigmentasi, soliter, bentuk oval, ukuran $3 \times 2 \mathrm{~cm}$, tampak erosi multiple, batas tegas, bentuk bulat, ukuran diameter $0,3-0,4 \mathrm{~cm}$, ditutupi krusta kehitaman di atasnya.

Kesimpulan: Diagnosis KSB ditegakkan berdasarkan anamnesis, pemeriksaan fisik, pemeriksaan dermoskopi dan histopatologi dengan terapi standar bedah eksisi elips.

Kata Kunci: Karsinoma sel basal, eksisi elips, tumescent

Site Pasal ini: Darmaputra I.G.N., Wardhana, Made., Adhilaksman, I.G.N., Indira, I.G.A.A.E., Suryawati, N. 2019. Karsinoma sel basal tipe nodular yang diterapi dengan bedah eksisi elips dan anastesi tumesen. Intisari Sains Medis 10 (1): 192-196. D0I: 10.1556/ism.v10i1.439

\section{PENDAHULUAN}

Karsinoma sel basal (KSB) merupakan keganasan kulit berasal dari sel yang tidak mengalami keratinisasi dan terdapat pada lapisan basal di epidermis. Karsinoma sel basal yang juga disebut sebagai basalioma merupakan kanker kulit non melanotik yang paling sering dijumpai pada manusia. ${ }^{1}$ Manifestasi klinis KSB sangat bervariasi, dan lesi umumnya muncul pada area terpapar sinar matahari seperti kepala dan leher. ${ }^{2,3}$
Angka insidensi KSB meningkat dari tahun ke tahun, antara lain disebabkan oleh perubahan kebiasaan sehari-hari yang berhubungan dengan pola paparan radiasi UV dan penggunaan bahan perusak ozone. Selain hal tersebut didapatkan peningkatan kesadaran masyarakat tentang bahaya keganasan kulit. ${ }^{4}$

Predileksi utama KSB adalah area yang terpapar sinar matahari, sekitar $80 \%$ mengenai kepala dan leher dan sebesar $30 \%$ terjadi pada hidung. Hal 
ini sesuai dengan teori yang menyatakan radiasi ultra violet (UV) sebagai faktor risiko utama KSB. Selain paparan UV, telah diketahui beberapa faktor risiko terjadinya KSB antara lain genodermatosis, imunosupresi serta paparan berbagai karsinogen lain.,

Jumlah kasus KSB di Amerika Serikat pada tahun 1996 sekitar 500.000 kasus, tahun 2002 sebesar 900.000 kasus dan tahun 2005 meningkat menjadi 1.000.000 kasus. Insiden KSB tertinggi di dunia terdapat di Australia dengan 726 kasus (100.000 penduduk/tahun). ${ }^{6,7}$ Sedangkan di RSUP Sanglah Denpasar pada bulan Januari 2017 - Agustus 2018 didapatkan sebanyak 9 pasien dengan diagnosa KSB baru. ${ }^{8}$ Pengklasifikasian dan dignostik KSB secara histopatologi penting untuk menentukan tipe tumor, perilaku biologis tumor, menentukan risiko kekambuhan dari penyakit ini dan untuk membandingkan modalitas terapi yang digunakan. ${ }^{1,9}$

Eksisi elips atau fusiformis merupakan salah satu prosedur bedah dalam bidang dermatologi yang paling sering digunakan. Eksisi elips diindikasikan untuk mengangkat neoplasma jinak atau ganas berukuran kecil sampai sedang. ${ }^{10,11}$ Teknik tumesen (tumescent) memungkinkan anestesi lokal regional pada kulit dan jaringan subkutan dengan menyebabkan infiltrasi langsung.

\section{LAPORAN KASUS}

Seorang perempuan, 64 tahun, no. CM. 18.03.11.71, suku Bali, pada tanggal 30 Juli 2018 datang ke Poliklinik Kulit dan Kelamin Rumah Sakit Sanglah dengan keluhan utama timbul luka pada dahi. Luka tersebut mulai timbul sejak 1 tahun yang lalu. Awalnya lesi berupa benjolan kecil berwarna kemerahan yang kemudian makin lama dirasakan makin melebar dan menjadi berwarna kehitaman serta disertai rasa gatal. Pasien mengatakan timbul luka di permukaan benjolan tersebut setelah sempat digaruk oleh pasien 3 bulan yang lalu. Luka tersebut dikatakan tidak pernah sembuh dengan sempurna. Keluhan nyeri tidak dikeluhkan oleh pasien. Riwayat penyakit terdahulu tidak ada.

Pasien pernah berobat ke Puskesmas 2 minggu yang lalu dan mendapatkan krim kloramfenikol tetapi pasien merasa belum membaik. Pasien kemudian pergi ke praktek dokter spesialis kulit dan dirujuk ke Poliklinik Kulit dan kelamin Rumah Sakit Umum Pusat Sanglah Denpasar. Tidak ada anggota keluarga pasien yang mengalami keluhan yang sama dengan pasien. Pasien adalah seorang ibu rumah tangga. Pasien mengatakan dirinya terpapar sinar matahari saat menjemur pakaian, terutama pada siang hari saat suhu panas, walaupun tidak lama, pasien terpapar sinar matahari hampir setiap hari. Pasien mengatakan tidak pernah menggunakan tabir surya pada kulit wajah ataupun badannya.

Pada pemeriksaan fisik ditemukan keadaan umum baik, kesadaran kompos mentis. Tekanan darah: 110/70 $\mathrm{mmHg}$, denyut nadi: $80 \mathrm{x} / \mathrm{menit}$, frekwensi pernafasan: 20x/menit, suhu aksila : $36,5^{\circ} \mathrm{C}$ dan berat badan $63 \mathrm{~kg}$. Pada status generalis pasien didapatkan kepala normocephali, tidak didapatkan adanya tanda-tanda anemia dan ikterus pada kedua mata. Pada pemeriksaan telinga, hidung, dan tenggorokan tidak ditemukan adanya kelainan. Pada leher dan aksila tidak didapatkan pembesaran kelenjar getah bening. Suara jantung (S1 dan S2) tunggal, reguler, tidak terdapat murmur. Ditemukan suara nafas vesikuler, tidak ditemukan adanya ronkhi dan wheezing. Hepar dan lien tidak teraba, bising usus dalam batas normal, dan tidak terdapat distensi abdomen. Pada ekstremitas teraba hangat, tidak ditemukan edema.

Pemeriksaan dermatologi pada lokasi dahi (frontalis) tampak plak hiperpigmentasi, soliter, bentuk oval, ukuran $3 \times 2 \mathrm{~cm}$, tampak erosi multiple, batas tegas, bentuk bulat, ukuran diameter 0,3$0,4 \mathrm{~cm}$, ditutupi krusta kehitaman di atasnya. Diagnosis banding pada pasien saat ini adalah karsinoma sel basal dan karsinoma sel skuamosa. Pemeriksaan penunjang yang direncanakan antara lain pemeriksaan dermoskopi dan pemeriksaan histopatologi. Pada pemeriksaan dermoskopi tampak lesi asimetris, batas ireguler, warna heterogen, tampak teleangiektasis dengan pola yang tidak teratur (arborizing vessels), struktur globus memperlihatkan gambaran globus multipel berwarna biru keabuan (blue gray globules), dan ulserasi.

Berdasarkan anamnesis, pemeriksaan fisik dan pemeriksaan penunjang diagnosis pasien saat ini adalah suspek karsinoma sel basal dengan diagnosis banding karsinoma sel skuamosa. Penatalaksanaan pada pasien adalah rencana eksisi biopsi dengan pemeriksaan histopatologi setelah paisien siap dan mengurus BPJS. Pasien juga diberikan krim antibiotik gentamisin $0,3 \%$ yang dioleskan pada lesi di dahi setiap 12 jam. Pasien datang kembali pada tanggal 15 Agustus 2018 untuk dilakukan bedah eksisi bentuk elips dan pemeriksaan histopatologi pada jaringan pasca operasi.

Setelah pasien memahami tindakan yang akan dilakukan, pasien diminta untuk menandatangani surat persetujuan operasi (inform consent). Selanjutnya pasien diminta berbaring di meja operasi dengan posisi terlentang. Sebelum operasi dimulai, dilakukan persiapan alat-alat yang akan digunakan (Gambar 2a). Pada daerah lesi dibuat pemetaan (marker) dengan safety margin 0,5 

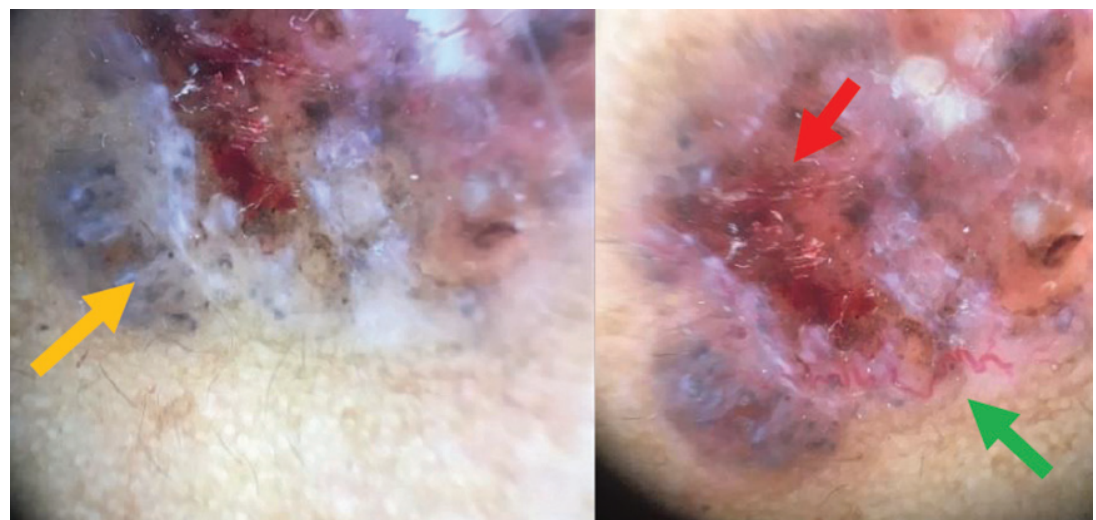

Gambar 1. Gambaran lesi pada dahi pasien dilihat melalui dermoskop. Tampak lesi asimetris, batas ireguler, warna tidak homogen, arborizing vessels (tanda panah hijau), blue gray globules (tanda panah kuning), dan ulserasi (tanda panah merah).

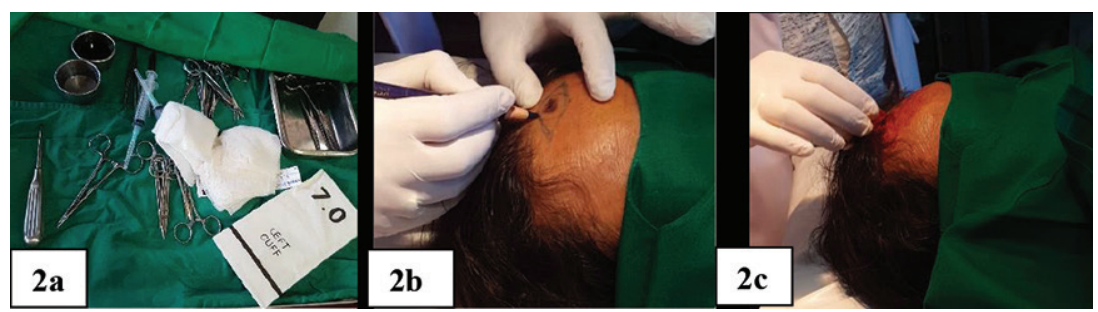

Gambar 2. (a) Persiapan alat; (b) Marker; (c) Tindakan aseptik.
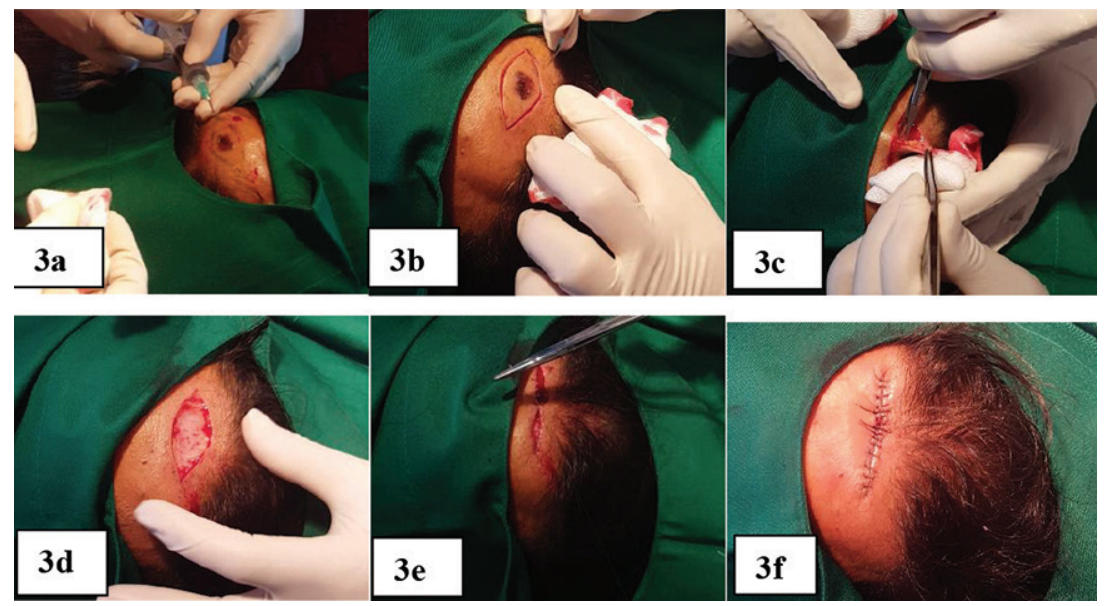

Gambar 3. (a) Teknik tumesen lokal; (b) Insisi bentuk elips; (c) Pengangkatan jaringan; (d) Undermining dan perdarahan minimal; (e) Hecting; (f) Luka dibersihkan povidon iodine $+\mathrm{Nacl}$ 0,9\%, kemudian dikeringkan

$\mathrm{cm}$, berbentuk elips dengan perbandingan 3:1 (Gambar 2b), lalu lapangan operasi didesinfeksi dengan menggunakan larutan povidon iodine 10\% dan dipersempit dengan melakukan penutupan menggunakan doek steril. (Gambar 2c). Selanjutnya dilakukan injeksi anestesi dengan teknik tumesen pada daerah disekitar lesi (Gambar 3a). Pada tumor dilakukan eksisi sesuai dengan marker yang dibuat mengelilingi lesi menggunakan skalpel (Gambar 3b). Kemudian lesi diangkat dan dipisahkan dari jaringan dibawahnya (Gambar 3c) dan dilakukan undermining serta penekanan dengan kassa steril untuk menghentikan pendarahan (Gambar 3d). Kulit dijahit dengan teknik simple interrupted sutures menggunakan benang nilon 4.0 (Gambar 3e). Luka dibersihkan dengan povidon iodine $10 \%$ dan $\mathrm{NaCl}$ 0,9\% kemudian dikeringkan (Gambar 3f). Setelah tindakan operasi selesai, dioleskan salep gentamisin $0,3 \%$ pada daerah penjahitan dan luka operasi ditutup dengan hipafiks.

Terapi pasca operasi adalah pemberian antibiotik cefadroxil $500 \mathrm{mg}$ setiap 12 jam per oral selama 7 hari, asam mefenamat $500 \mathrm{mg}$ setiap 8 jam per oral bila nyeri dan pada pasien diberikan edukasi untuk menjaga luka jahitan agar tetap bersih dan kering. Pasien direncanakan kontrol keesokan harinya pasca operasi.

\section{Pengamatan Lanjutan}

Pasien dianjurkan untuk melakukan kunjungan rutin sebagai bagian dari pengamatan lanjutan. Pada hari ke-1 pasca tindakan operasi (16 Agustus 2018) dan hari ke-5 (20 Agustus 2018), luka tertutup dengan baik, tidak ada edema, perdarahan, nekrosis, hematoma maupun tanda-tanda infeksi sekunder. Pada kunjungan hari ke-8 (23 Agustus 2018), dilakukan pengangkatan jahitan sebanyak 4 jahitan, lalu dioleskan gentamisin 0,3\% krim topikal ditutup dengan kassa steril. Pasien direncanakan kontrol 4 hari kemudian (Gambar 4).

Pada hari ke-12 (27 Agustus 2018), pemeriksaan histopatologi menyimpulkan adanya sediaan potongan jaringan terdiri dari lapisan epidermis, dermis dan subkutis. Pada lapisan dermis tampak proliferasi sel-sel basal neoplastik yang tersusun nodular dengan peripheral palisading dan cleft artefact di bagian tepi dan haphazard di bagian tengah. Sel-sel neoplastik tersebut berbentuk bulat, relatif uniform, inti bulat, pleomorfia inti ringan sampai sedang, hiperkromatik, membran inti ireguler, mitosis dapat ditemukan, tepi-tepi dan dasar reseksi tidak mengandung sel karsinoma. Kesimpulan gambaran morfologi sesuai untuk karsinoma sel basal tipe nodular di mana tepi-tepi dan dasar reseksi tidak mengandung sel karsinoma (Gambar 5).

Diagnosis kerja pada pasien ini adalah follow up karsinoma sel basal pasca operasi hari ke-12. Penatalaksanaan yang diberikan adalah rawat luka, luka dibersihkan dengan larutan Nacl 0,9\%, pengangkatan jahitan sebanyak 9 jahitan, lalu dioleskan gentamisin 0,3\% krim topikal ditutup dengan kassa steril. Pasien direncanakan kontrol 3 hari kemudian. Pada hari ke-15 (30 Agustus 


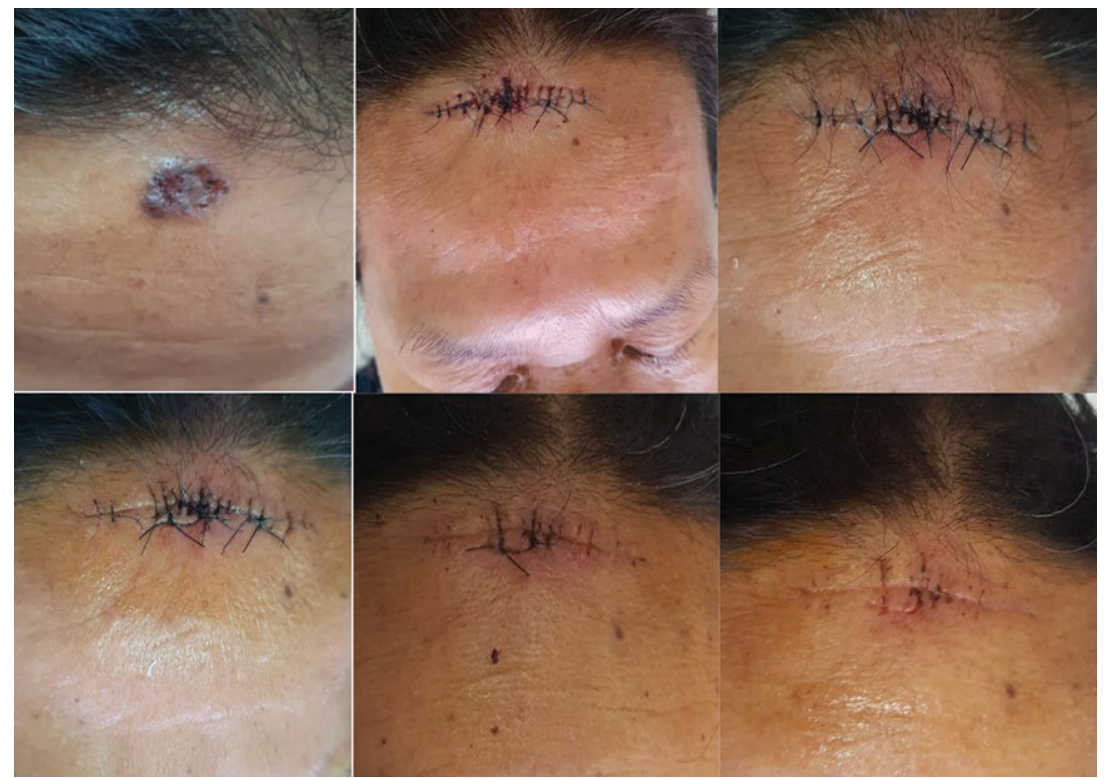

Gambar 4. (Atas: kiri-kanan) Lesi sebelum tindakan bedah eksisi elips; Luka jahitan pada dahi pasien hari ke-1 pasca operasi; Luka jahitan pada dahi pasien hari ke-5; (Bawah: kiri-kanan) Pengangkatan 4 jahitan pada hari ke-8; Pengangkatan 9 jahitan pada hari ke-12; Pengangkatan jahitan sisa pada hari ke-15.
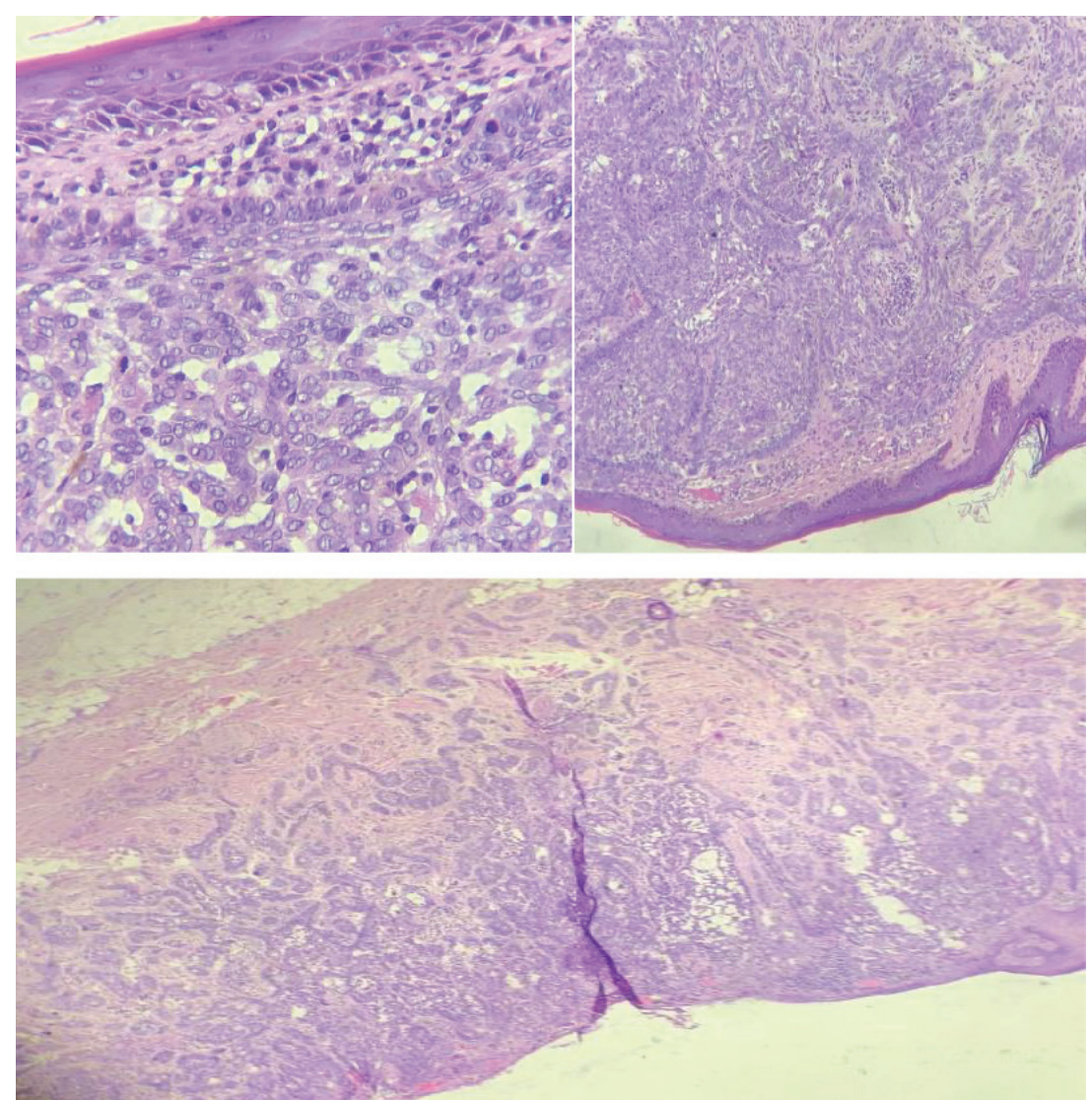

Gambar 5. (Kiri Atas) Sel-sel neoplastik berbentuk bulat, relatif uniform, inti bulat, pleomorfia inti ringan sampai sedang, hiperkromatik, membrane inti ireguler; (Kanan Atas) Tampak cleft artefact dan haphazard; (Bawah) Proliferasi sel-sel basal neoplastik yang tersusun nodular dengan peripheral palisading.
2018), langkah akhir adalah pengangkatan jahitan sebanyak 3 jahitan, lalu dioleskan gentamisin 0,3\% krim topikal ditutup dengan kassa steril untuk sementara. Selain itu diberikan juga penjelasan bahwa pasien perlu kontrol pada tahun ketiga atau kelima setelah pengobatan atau kontrol segera apabila ada keluhan.

\section{PEMBAHASAN}

Karsinoma sel basal adalah tumor kulit yang dapat dijumpai pada setiap usia tetapi lebih sering ditemukan pada orang tua. Faktor risiko terjadinya KSB antara lain karakteristik fenotif pasien seperti warna kulit; risiko lingkungan terutama radiasi ultraviolet B; paparan sebelumnya dengan arsenik; usia tua; imunosupresi; radioterapi dan riwayat kanker kulit non melanoma pada keluarga. ${ }^{12,13}$

Karsinoma sel basal tipe nodular merupakan subtipe KSB yang paling sering ditemukan (50$80 \%$ ) dan sebagian besar muncul pada area tubuh yang terpapar sinar matahari. Tipe ini memiliki karakteristik papul dan nodul yang menyerupai mutiara, waxy atau translusen, disertai adanya teleangiektasis tipikal pada pemeriksaan dermoskopi. ${ }^{1,3}$ Dalam perkembangannya, dapat terjadi ulserasi pada daerah sentral yang tidak terasa nyeri dan tertutup krusta, ulkus ini dikenal sebagai ulcus rodent. Adanya ulkus ini menandakan suatu proses kronis yang berlangsung selama berbulanbulan hingga bertahun-tahun dan perlahan-lahan dapat bertambah besar. ${ }^{5}$

Bedah eksisi dan MMS diikuti dengan konfirmasi histopatologi merupakan gold standard pada KSB risiko tinggi. ${ }^{16}$ Tujuan utama berbagai prosedur eksisi adalah untuk mengangkat tumor secara keseluruhan.,17 Eksisi elips diindikasikan untuk mengangkat neoplasma jinak atau ganas yang berukuran kecil sampai sedang. ${ }^{11}$ Eksisi elips memberikan kosmetika yang baik dengan meminimalkan pengangkatan jaringan, pergerakan kulit dan panjang insisi. ${ }^{18,23}$ Untuk hasil kosmetik yang optimal eksisi elips harus diorientasikan sepanjang RSTL, yang secara umum tegak lurus terhadap tarikan otot di area tersebut. ${ }^{19}$

Teknik tumesen memungkinkan anestesi lokal regional pada kulit dan jaringan subkutan dengan menyebabkan infiltrasi langsung. Infiltrasi dimulai perlahan dan secara bertahap dipercepat. Infiltrasi subkutan yang lebih dalam dilakukan terlebih dahulu, kemudian dilanjutkan dengan lapisan atas subkutan. Obat anestesi disuntikkan sampai jaringan lemak membengkak dan mengeras. ${ }^{20-22}$

Teknik tumesen memiliki berbagai keuntungan, seperti mengurangi jumlah perdarahan, efek anastesi yang lebih lama, kesembuhan luka yang lebih cepat, melindungi oragan yang berada 
di bawah kulit, dan juga dapat mengurangi kemungkinan untuk infeksi. ${ }^{20}$ Prognosis pada pasien karsinoma sel basal umumnya baik. Pasien harus melakukan follow-up setelah prosedur terapi untuk melihat adanya tanda-tanda rekurensi dan umumnya follow-up dilakukan pada tahun ketiga dan tahun kelima. ${ }^{8}$

\section{SIMPULAN}

Terdapat satu kasus KSB tipe nodular pada seorang perempuan berusia 64 tahun. Diagnosis ditegakkan berdasarkan anamnesis, pemeriksaan fisik, pemeriksaan dermoskopi dan histopatologi. Tindakan bedah eksisi elips merupakan pengobatan standar yang sangat efektif untuk KSB, dengan safety margin $0,5 \mathrm{~cm}$. Prognosis pada kasus ini adalah dubius.

\section{DAFTAR PUSTAKA}

1. Carucci JA, Leffell DJ. Basal Cell Carcinoma. In: Freedberg IM, Eisen AZ, Wolf K, editors. Fitzpatrick's dermatology in general medicine. 7 th ed. Philadelphia:WB Saunders Co; 2008. p. 1036-42.

2. Nouri K., Ballard C.J., Patel A.R., Braise R.A. Basal Cell Carcinoma. In: Nouri K., editors. Skin Cancer. New York: McGraw-Hill; 2008.p.61-85.

3. Reinau D., Surber C., Jick S.S., Meier C.R. Epidemiology of basal cell carcinoma in the United Kingdom: incidence, lifestyle factors, and comorbidities. British J Cancer. 2014; 111: 203-6.

4. Ramsey ML. Basal Cell Carcinoma. Emedicine May[cited 2006 May 9]. Available from: URL: http:///www.emedicine. com/derm/topic47.htm.

5. Rubin AI, Chen EH, Ratner D. Current Concepts Basal Cell Carcinoma. N Engl J Med 2005; 353: 2262-9.

6. Carucci J.A., Leffell D.J., Pettersen J.S. Basal Cell Carcinoma. In: Goldsmith L.A., Katz S.I., Gilchrest B.A., Paller A.S., Leffell D.J., Wolf K., editors. Fitzpatrick's Dermatology in General Medicine. $8^{\text {th }}$ ed. New York: McGraw-Hill; 2012.p.1294-1303.

7. Chinem V.P. and Miot H.A. Epidemiology of Basal Cell Carcinoma. An Bras Dermatol. 2011; 86(2): 292-305.

8. Anonim. Buku Register Kunjungan Sub Bagian Tumor Bedah Kulit, Poliklinik Kulit dan Kelamin Rumah Sakit Umum Pusat Sanglah. Denpasar; 2017-2018.

9. Strutton G. Tumors of The Epidermis. In : Weedon D. Ed. Skin Pathology $2^{\text {nd }}$ ed. New York : Churchill Livingstone, 2002, $\mathrm{p}:$ 753-802.

10. Wong CSM, Strange RC, Lear JT. Basal cell Carcinoma. BMJ 2003;327:794-798.
11. Robinson JK. Excisional Surgery and Repair, Including Flaps and Grafts. In : Wolff k, Goldsmith LA, katz SI, Gilchrest BA, Paller AS, Leffel DJ, editors. Fitzpatrick's Dermatology in General Medicine, $7^{\text {th }}$ ed. USA : McGrawHill Company, 2008, p : 2302-2315.

12. Jiang SB, Szyfelbein K. Pathology : Basal cell carcinoma. Available at : http://www.emedicine.com/ent/disc672.htm. Last update : Aug 162007.

13. Niwa ABM, Pimentel ERA. Basal cell Carcinoma in Unusual Locations. An Bras Dermatol. 2006;81(5 supl 3):s281-4.

14. Wong CSM, Strange RC, Lear JT. Basal cell Carcinoma. BMJ 2003;327:794-798.

15. Grossman D, Leffell DJ. Squamous Cell Carcinoma. In : Wolff k, Goldsmith LA, katz SI, Gilchrest BA, Paller AS, Leffel DJ, editors. Fitzpatrick's Dermatology in General Medicine, $7^{\text {th }}$ ed. USA : McGraw-Hill Company, 2008, p : 1028-1036.

16. Kimyai-Asaidi A, Alam M, Goldberg LH, et all. Efficacy of Narrow-Margin Excision of WII-demarcate Primary Facial Basal Cell Carcinoma. J Am Acad Dermatol. 2005;42:446452.

17. Telfer NR, Colver GB, Bowers PW. Guidelines for The Management of Basal cell Carcinoma. Br J Dermatol 1999;141:415-423.

18. Goldberg LH, Alam M. Elliptical Excisions. Arch Dermatol. 2004;140:176-180.

19. Aasi SZ, Pennington B. Surgery in Dermatology. In : Wolff k, Goldsmith LA, katz SI, Gilchrest BA, Paller AS, Leffel DJ, editors. Fitzpatrick's Dermatology in General Medicine, $7^{\text {th }}$ ed. USA : McGraw-Hill Company, 2008, p : 2289-2301.

20. Gadelha A, Leão TL. Rule of four: a simple and safe formula for tumescent anesthesia in dermatologic surgical procedures. Surgical \& Cosmetic Dermatology. 2009; 1(2):99-102

21. Hruza GJ. Anesthesia. Dalam: Bolognia J, Jorizzo JL, Rapini RP, editor. Dermatology. Toronto: Mosby;2003.h.2233-9.

22. Klein JA: Tumescent technique for regional anesthesia permits lidocaine doses of $35 \mathrm{mg} / \mathrm{kg}$ for liposuction: Peak plasma lidocaine levels are diminished and delayed 12 hours. J Dermatol Surg Oncol. 1990; 16:248-263

23. Ridha, M., Suyatno, S., Pasaribu, E. 2017. Comparison of total seromas between Modified Radical Mastectomy (MRM) with and without skin flap fixation at Dr H. Adam Malik Hospital, Medan Indonesia. Bali Medical Journal 6(2): 357-362. DOI:10.15562/bmj.v6i2.574

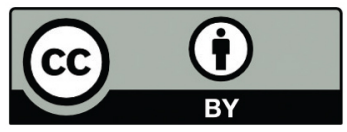

This work is licensed under a Creative Commons Attribution 